\title{
Entrepreneurship Development of Tribal Women through KVK Activities
}

\author{
Vilas Jadhav* and J. Venkat Pirabu \\ Agriculture Extension \& Rural Sociology Department of TNAU, Coimbatore, India \\ *Corresponding author
}

\section{A B S T R A C T}

In the present scenario of globalization, liberalization and privatization of agricultural sector, the sustainable development and empowerment of farm women is considered as a key factor for development of any country. According to the 2011 census of India, women constitute half of the total population.

Keywords

Entrepreneurship, Empowerment, Sustainable development, Self help group, KVK, ICAR, Demonstration, Training

Article Info

Accepted: 10 July 2019 Available Online: 10 August 2019 Participation of women in economic activities is now emerging as a universal phenomenon. Advancement of information and communication technologies created many opportunities for the development of talents of women in entrepreneurship activities. Krishi Vigyan Kendra, funded by a renowned institute, Indian Council of Agricultural Research provides vocational training programmes to the farm women for their self employment. The study was conducted in Jawhar and Mokhada tehesil of Palghar district of Maharashtra state. The two tribal dominated tehsils were selected purposively. 10 villages selected randomly where KVK Palghar was implemented their entrepreneurial activities conducted for SHG tribal women. 02 SHGs from each village were selected for the study. A SHG having 10 members i.e. each 20 members from 02 SHGs i.e. 200 members from 20 SHGs were benefitted from entrepreneurial activities of KVK. Those SHGs members were trained by KVK on Value addition in finger millet, Poultry management, Jasmine production and Goat Keeping. It was highlighted from the results that, income received from entrepreneurial activities was 48,400/- and agricultural income received as on average Rs.46,557/- per year, i.e. total income reported from family was Rs. 94987/- per year. Study also revealed various aspects of entrepreneurial activities like, impact on employment generation, structure of house, material possession, consumption and impact on saving. Hence policy makers and administrators have to give priority for formation of women SHG and provide financial assistance for establishing their own agro based enterprises.

\section{Introduction}

"You can tell the condition of a nation by looking at the status of its women" Jawaharlal Nehru.

The emergence of women entrepreneurs and their contribution to the national economy is quite visible in India. The number of women entrepreneurs has grown over a period of time, especially in the 1990s. Women entrepreneurs need to be lauded for their increased utilization of modern technology, increased investments, finding a niche in the export market, creating a sizable employment for others and setting the trend for other women entrepreneurs in the organized sector. While women entrepreneurs have demonstrated their potential, the fact remains that they are capable of contributing much more than what they already are. Women's entrepreneurship needs to be studied separately for two main reasons. The first reason is that women's entrepreneurship has been recognized during the last decade as an important untapped source of economic growth. Women entrepreneurs create new jobs for themselves and others and also by being different. 
Rural women play a vital role in farm and home system. She contributes substantially in the physical aspect of farming, livestock management, post-harvest and allied activities. Her direct and indirect contribution at the farm and home level along with livestock management operation has not only help to save their assets but also led to increase the family income. She performs various farm, livestock, post-harvest and allied activities and possesses skills and indigenous knowledge in these areas. The women were empowering themselves technically to cope with the changing times and productively using their free time and existing skills for setting and sustaining enterprises. They were engaged in starting individual or collective income generation programmes with the help of selfhelp group. This will not only generate income for them but also improve the decision-making capabilities that led to overall empowerment.

Agricultural production of the Palghar district is mainly depends upon tribal women. They are engaged in tedious job like rice transplanting and harvesting of rice as well as grass cutting which is the main economic source. It means tribal women has significant role in home as well as farming activities.

Tribal are still using the traditional practices that cause low income and less productivity as compare to other communities. This is one of the main reasons for their poverty. In to upgrade their socio- economic status, the only option today is to improve their agricultural productivity through the adoption of improved technologies. In to boost up the overall agricultural productivity tribal women plays a key role in changing the traditional practices. Therefore the role of women should be given emphasis so that the desirable changes can be brought about in lifestyle of tribal masses.

Keeping these things in mind, the KVK, Palghar (MS) started its intervention. KVK has given an opportunity with due attention to their specific farming responsibilities and arranged various vocational training programme for promoting women participation and contribution in agricultural production. After providing training programmes many farm women were started agricultural based enterprises individually as well as SHGs for their self-employments.

Entrepreneurship development and income generating activities of $\mathrm{KVK}$ are a feasible solution for empowering women.It generates income and also provides flexible working hours according to the needs of home makers. Thus, to investigate the entrepreneurship development of tribal women through KVK activities, the present study was undertaken to study an impact of entrepreneurial activities on SHG tribal women with this specific objectives:

\section{Materials and Methods}

The study was conducted in Jawhar and Mokhada, the tribal dominated tehsils of Palghar district of Maharashtra state were selected purposively. 10 villages selected randomly where KVK Palghar was implemented their entrepreneurial activities for SHG tribal women. 02 SHGs from each village were selected for the study. A SHG having 10 members i.e. each 20 members from 02 SHGs i.e. 200 members from 20 SHGs were benefitted from entrepreneurial activities of KVK. Those SHGs members were trained by KVK on Value addition in finger millet, Poultry management, Jasmine production and Goat Keeping.

Study also revealed various aspects of entrepreneurial activities like, impact on employment generation, structure of house, material possession, consumption and impact on saving. Thus, total respondents were 200 women selected for the study. The interview 
schedule was pretested. Personal interview technique was used for data collection. The data collected from the respondents were processed and tabulated. Frequency and percentage used for statistical methods.

\section{Results and Discussion}

An attempt has been made to access the impact of entrepreneurial activities of KVK Palghar on the SHG tribal women, major components have been identified, finalized and the same has been used as discussed in the methodology chapter. The relevant data were collected with the help of identified components, tabulated, analysed and the results are presented in this section.

\section{Impact on income position of the SHG} tribal women

Any attempt to measure the impact of entrepreneurial activities of KVK should entail an two periods before and after implementing the entrepreneurial activity. Data were collected on these lines and presented in following Table 1.

From the above table, it could be concluded that the before joining or participating training programmes respondents had very low income i.e. Rs.25,325/- per year. The family belonged to below poverty line. They approached KVK for getting training on income generating activities. Hence, KVK organized training programmes after taking consideration of their interest.

The respondents had received an average income of Rs. 94987/- per year after getting training. It influences to another family members who were also adopted latest technologies in filed. So the income level of whole family increased. Nearly half of the incomes gained from adopting entrepreneurial activities like value addition in finger millet,
Poultry management, Jasmine production, Goat Keeping. These entrepreneurial activities were plays as major source of income of their family which helped to earn more money for improving their livelihood security.

\section{Impact on employment generation}

The data pertaining to employment generation was analyzed and presented in Table 2 .

It is observed from the Table 2, majority (96.00\%) of the SHG tribal women were selfemployed due to the entrepreneurial activities. They have been able to be increased in employment $(90.00 \%)$.

More so, the employment of the women $(88.00 \%)$ also got increased significantly, besides the seasonal employment (84.00\%) has also been on the increase and off seasonal employment opportunities also increased to the certain extent by $(60.00 \%)$.

\section{Impact on structure of house}

Impact on entrepreneurial programmes towards structure of house and the data on the development or modification of structure of house were collected and mentioned in Table 3.

The study clearly indicates that, majority $(67.50 \%)$ tribal women lived in mud walled and thatched house while 80.00 percent were electrified house were observed. Nearly 50.00 per cent tribal women had bathroom and toilet due to the compulsion from Gram Panchayat. It is mandatory requirement for tribal to get benefit of other schemes like Indira Awas Yojan, Gharkul Yojana, etc.

It is observed that only 4.00 per cent and 5.00 percent tribal women had structure of house as cement floor and had modern kitchen respectively. 
Table.1 Income generation

\begin{tabular}{|l|l|c|c|c|c|}
\hline $\begin{array}{l}\text { Sr. } \\
\text { No. }\end{array}$ & $\begin{array}{l}\text { Agriculture + } \\
\text { Horticulture + } \\
\text { Entrepreneurial } \\
\text { activity }\end{array}$ & $\begin{array}{c}\text { Income level of } \\
\text { respondent } \\
\text { (before } \\
\text { training) per } \\
\text { year/ person }\end{array}$ & \multicolumn{3}{|c|}{$\begin{array}{c}\text { Income level of respondents After training } \\
\text { per year /person }\end{array}$} \\
\cline { 5 - 7 } & & $\begin{array}{c}\text { Income } \\
\text { from } \\
\text { Agriculture } \\
\text { (Rs) }\end{array}$ & $\begin{array}{c}\text { Income from } \\
\text { Enterprise } \\
\text { (Rs) }\end{array}$ & $\begin{array}{c}\text { Total income of } \\
\text { respondents } \\
\text { (Rs.) }\end{array}$ \\
\hline $\mathbf{1}$ & $\begin{array}{l}\text { Value addition in } \\
\text { finger millet }\end{array}$ & Rs.26,800 & 52,948 & 42800 & Rs.95,748 \\
\hline $\mathbf{2}$ & Poultry management & Rs. 26,000 & 46900 & 51600 & Rs.98,500 \\
\hline $\mathbf{3}$ & Jasmine production & Rs. 25,500 & 41750 & 60500 & Rs. 1,02,250 \\
\hline $\mathbf{4}$ & Goat Keeping & Rs. 22,200 & 44750 & 38700 & Rs. 83,450 \\
\hline & Mean & Rs. 25,325 & 46557 & 48400 & Rs. 94,987 \\
\hline
\end{tabular}

Table.2 Distribution of respondents according to impact on employment generation

\begin{tabular}{|c|c|c|c|}
\hline \multirow[t]{2}{*}{ Sr. No. } & \multirow{2}{*}{ Components } & \multicolumn{2}{|c|}{ After started entrepreneurial activity } \\
\hline & & No. & percentage \\
\hline 1 & Self employment & 194 & 97.00 \\
\hline 2 & Increased days of employment & 180 & 90.00 \\
\hline 3 & $\begin{array}{l}\text { Increased days of employment for } \\
\text { women }\end{array}$ & 176 & 88.00 \\
\hline 4 & Seasonal employment & 168 & 84.00 \\
\hline 5 & $\begin{array}{l}\text { Off seasonal employment } \\
\text { opportunity }\end{array}$ & 120 & 60.00 \\
\hline
\end{tabular}

*Multiple responses

Table.3 Impact on structure of house

\begin{tabular}{|l|l|c|c|}
\hline Sr. No. & Structure of House & No of respondents & Percentage \\
\hline $\mathbf{1}$ & Mud walled and thatched house & 135 & 67.50 \\
\hline $\mathbf{2}$ & Mud walled and tiled house & 64 & 32.00 \\
\hline $\mathbf{3}$ & Brick walled and tiled house & 96 & 48.00 \\
\hline $\mathbf{4}$ & Brick walled and concrete roof & 24 & 12.00 \\
\hline $\mathbf{5}$ & Cement Floor/mosaic/ tile floor & 08 & 4.00 \\
\hline $\mathbf{6}$ & House having bath room & 102 & 51.00 \\
\hline $\mathbf{7}$ & House having toilet & 94 & 47.00 \\
\hline $\mathbf{8}$ & Electrified house & 160 & 80.00 \\
\hline $\mathbf{8}$ & House with modern kitchen & 10 & 5.00 \\
\hline
\end{tabular}

*Multiple responses 
Table.4 Impact of material position

\begin{tabular}{|l|l|c|c|}
\hline Sr. No. & Particular & No. of respondents & Percentage \\
\hline $\mathbf{1}$ & TV & 104 & 52.00 \\
\hline $\mathbf{2}$ & Radio & 57 & 28.50 \\
\hline $\mathbf{3}$ & Tape record & 34 & 17.00 \\
\hline $\mathbf{4}$ & Two Wheeler & 118 & 59.00 \\
\hline $\mathbf{5}$ & Four Wheeler & 0 & .000 \\
\hline $\mathbf{6}$ & Agricultural Machineries & 110 & 55.00 \\
\hline $\mathbf{7}$ & Horticultural Machineries & 42 & 21.00 \\
\hline $\mathbf{8}$ & Honey Collection equipents & 10 & 05.00 \\
\hline $\mathbf{9}$ & Mobile/ Android Mobile & 48 & 24.00 \\
\hline
\end{tabular}

*Multiple responses

Table.5 Impact on consumption pattern

\begin{tabular}{|l|l|c|c|}
\hline Sr. No. & Components & No. of respondents & Percentage \\
\hline $\mathbf{1}$ & Change in food habit & 164 & 82.00 \\
\hline $\mathbf{2}$ & Change in Clothing & 130 & 65.00 \\
\hline $\mathbf{3}$ & $\begin{array}{l}\text { Improving participation in religious } \\
\text { ceremony and marriage }\end{array}$ & 118 & 59.00 \\
\hline $\mathbf{4}$ & $\begin{array}{l}\text { Improve health } \\
\mathbf{5}\end{array}$ & 102 & 51.00 \\
\hline $\mathbf{6}$ & $\begin{array}{l}\text { Improve educational level } \\
\text { Helping to clear debts in bank and outside }\end{array}$ & 142 & 71.00 \\
\hline
\end{tabular}

Table.6 Impact on savings

\begin{tabular}{|c|c|c|c|}
\hline Sr. No. & Saving and debt Clearance & No. of respondents & Percentage \\
\hline 1 & Opened bank account & 200 & 100.00 \\
\hline 2 & Postal saving accounts & 56 & 28.00 \\
\hline 3 & Increased saving behaviour & 200 & 100.00 \\
\hline 4 & Availed Loans & 170 & 85.00 \\
\hline 5 & Repaid loans & 150 & 75.00 \\
\hline 6 & Increased income levels & 180 & 90.00 \\
\hline 7 & $\begin{array}{l}\text { Ability for external credit } \\
\text { mobilization }\end{array}$ & 80 & 40.00 \\
\hline 8 & $\begin{array}{l}\text { Reduced dependency on money } \\
\text { lenders }\end{array}$ & 164 & 82.00 \\
\hline
\end{tabular}

\section{Impact of material position}

The distribution of the respondents according to impact of material possession given in following table 4 .
It is observed from Table 4 that the SHG tribal women had increased their purchasing power agricultural machineries $(55.00 \%)$ like power tiller, conoweeder, sprayers, hand operated sprays, driers, etc. Nearly 59.00 per 
cent had possessed two wheeler (Motor Cycle) for their selling of agricultural produce in market places etc. Due to its costliness, nobody purchased four wheeler for transport. They usually prefer to travel by bus.

\section{Impact on consumption pattern}

To access the consumption pattern of the tribal women after joining SHG and participated in entrepreneurial activities conducted by KVK were collected and the results of the study is furnished in Table 5.

From above Table, it is clear that more than one third $(85 \%)$ tribal women clear debts in banks and outside sources due to became as member of SHG. It increased the habit to clear debt. It also observed that more than one third $(82.00 \%)$ had increased food habit due to the awareness from KVK towards balanced diet. They includes rice, dal, vegetables, proteins in daily diet. Entrepreneurial activities help to improve their educational level of tribal family. Due to its nearness of Primary, Secondary residential Ashram School it helps to increase the educational level. Tribal women sent their children to these schools where Government provided with free text books, uniforms annually, food etc.

\section{Impact on savings}

To know the levels of improvement on saving and investments of members after joining SHG and running enterprise were collected and displayed in Table 6.

From above Table, it is clear indicated that as all the respondents $(100.00 \%)$ were the members of SHG so they had possessed own back account as well as they saved fixed amount which was decided by SHG group hence, saving behaviour also increased with they able to accelerate the amount from agricultural and entrepreneurial activities. The SHG tribal women were runs income generating activities under the guidance of KVK which help to increase income level of the respondents. More than one third $(85 \%$ and $75.00 \%$ ) member were strictly follow the rules of SHG to avail the loan which could be used to expended in house renovation, daughter marriage, medical treatment etc and repaid loan within time limit while remaining had not necessary to avail the loans. It also helps to reduced dependency on money lender.

It could be concluded from the findings that, this study has brought to limelight the personal and socioeconomic characteristics of women entrepreneurs. On the basis of this, it would be possible for the extension worker and other agencies to identify the prospects of entrepreneurs. This would help in making the job of extension worker easier and would also save their time. Secondly, special efforts need to be made to convince these traditional entrepreneurs about new recommended technologies by organizing the practical oriented training classes in the villages, where the particular agricultural enterprises is run extensively. Thirdly, younger entrepreneurs having higher self-confidence, decision making after training received by $\mathrm{KVK}$, so some of these characteristics should be manipulated suitably, wherever possible to improve the Entrepreneurial behaviour of the entrepreneurship.

\section{References}

Anonymous (1998) A study of Entrepreneurial behaviour of youth. A report of the Agricultural Extension, Agricultural Economics and Agricultural Statistics subcommittee, Dr. Balasaheb Sawant Konkan Krishi Vidyapeeth, Dapoli.

Patil A. S. (1999): A study of Entrepreneurial 
behaviour of the vegetables in Raigad district. M. Sc. (Agri) Thesis (Unpublished), Dr. Balasaheb Sawant Konkan Krishi Vidyapeeth, Dapoli.

Ram Naresh Thakur (2009). "Rural Women Empowerment in India" in Empowerment of Rural Women in India Kanishka Publishers, New Delhi.

Shobana Nelasco and Junofy Antorozarina (2009) "Rural women empowerment through Self Help Groups" in
Empowerment of Rural Women in India Kanishka Publishers, New Delhi.

Suresh K. (2008): Impact of micro Finance on empowerment of rural women - a case study of dairy enterprise in the tank management project area of North Karnataka. M. Sc. (Agri) Thesis (Unpublished), Department of Agricultural Economics College of Agriculture, Dharwad University of Agricultural Sciences, Dharwad.

\section{How to cite this article:}

Vilas Jadhav and Venkat Pirabu, J. 2019. Entrepreneurship Development of Tribal Women through KVK Activities. Int.J.Curr.Microbiol.App.Sci. 8(08): 1144-1150.

doi: https://doi.org/10.20546/ijcmas.2019.808.134 